\title{
Partial Purification of Extracellular Cellulase from Pyricularia oryzae and Comparison of the Elution Patterns among Various Strains ${ }^{\dagger}$
}

\author{
Tadashi Sudo, Hideo Nagayama* and Kinjiro Tamari \\ Department of Agricultural Chemistry, Faculty of Agriculture, Tohoku University, Sendai \\ *The Research Institute for Tuberculosis, Leprosy and Cancer, \\ Tohoku University, Sendai
}

Received May 21, 1973

\begin{abstract}
In order to explain the difference in extracellular cellulase activities $\left(C_{1}\right.$ and $C_{x}$ enzyme activities) among various strains of $P$. oryzae, the elution patterns from the column were compared among various strains, following each step of the partial purification.

The crude enzymes, prepared by ammonium sulfate fractionation (0.2 0.8 sat.) from the culture filtrates, which were obtained from various strains of $P$. oryzae cultured on rice plant powder as the carbon source, were fractionated by DEAE-Sephadex A-50 chromatography into two components; the passing-through fraction (I) and the fraction (II) adsorbed and eluted from the column with $0.5 \mathrm{M} \mathrm{NaCl}$. The percentage of the enzyme activity $\left(C_{x}\right.$ enzyme activity) in fraction I to that of the crude extract was found to vary chracteristically according to the strain, and the variation was in a good correlation to that of the extracellular cellulase activities.

Fractions I and II were then separated by Sephadex G-100 into two (peaks a and b) and at least five (peaks $c, d, e, f$ and $g$ ) components, respectively. The activities in peaks $a, b$ and $\mathrm{g}$ were found to vary according to the strain, while those of peaks $\mathrm{c}$ and $\mathrm{e}$ were common among various strains.

The cell wall fraction prepared from $\mathrm{C}-3$ strain, which was previously shown to be low in enzyme activity and thus out of the correlation between the degree of pathogenicity and extracellular cellulase activity, was found to exhibit higher cellulase activities $\left(C_{1}\right.$ and $C_{x}$ enzyme activities) than those of other strains examined. Thus, the low extracellular cellulase activity in the case of $\mathrm{C}-3$ strain was suggested to be due to the abnormality in the mechanism of enzyme excretion.
\end{abstract}

Our studies have been carried out on cellulase activity in $P$. oryzae, considered to be concerned with the degradation of cellulose, one of the cell wall components of the plant, in order to obtain the fundamental findings utilizable for classifying various races (i.e., $\mathrm{T}, \mathrm{C}, \mathrm{N}$ and $O$ ) of $P$. oryzae according to the activity of this enzyme.

In the previous paper, ${ }^{11}$ conditions of measuring the extracellularly excreted cellulase were investigated, using the culture fluids of various representative strains cultured on rice plant powder as the carbon source; i.e., the time course of the enzyme production,

$\uparrow$ Comparative Biochemical Studies on Cellulase in Pyricularia oryzae Cavara. Part II. the time course of hydrolysis of carboxymethylcellulose (CMC), and some enzymatic properties of extracellular cellulase. Then, comparing the cellulase activities among various strains under standardized conditions, a correlation was found between the cellulase activities and the degree of pathogenicity of each strain except for the case of $\mathrm{C}-3$ strain.

In the present work, a partial purification of the cellulase was carried out to account for the difference in extracellular cellulase activities among various strains, and the characteristic correlation was also revealed between the elution patterns from the columns and the degree of pathogenicity of each strain. Further, in the case of $\mathrm{C}-3$ 
strain, which forms an exception to the correlation observed thus far, a possible explanation of the reason for its being an exception was sought, and rather higher activity than other strains was found in the cell wall fraction of this strain.

\section{MATERIALS AND METHODS}

Microorganism. Strains used throughout this experiment were the following 12 strains of $P$. oryzae; $\mathrm{T}-1$ (Ken 53-33), T-2 (Hiro 63-20), T-2 (Ken 62-89), C-1 (TH 62-132), C-1 (Ken 69-08), C-3 (N 87), C-3 (F 67-2), N-1 (H 373), N-1 (Ken 69-07), O (THU $3 \times 1$ ), $O$ (THU 65-01) and $O$ (S 1-19). Of these strains, $\mathrm{T}-1$ (Ken 53-33), $\mathrm{C}-3$ (N 87) and N-1 (H 373) strains were given by Dr. J. Kozaka at National Institute of Agricultural Science, and T-2 (Hiro 63-20), T-2 (Ken 62-89), C-1 (TH 62-132), C-1 (Ken 69-08), C-3 (F 67-2), $\mathrm{N}-1$ (Ken 69-07), O (THU $3 \times 1$ ) and $\mathrm{O}$ (THU 65-01) strains were presented by Dr. S. Yamanaka at the Department of Pathology, Faculty of Agriculture, Tohoku University. O (S 1-19) strain of P. oryzae was given by Dr. N. Ogasawara at the Department of Applied Biochemistry, Faculty of Agriculture, Niigata University.

Culture. The organisms were grown on rice plant powder as a carbon source, as described in the previous paper. ${ }^{11}$

Preparation of crude enzyme. After culturing, rice plant powder and cells in the culture were removed by gauze filtration and centrifugation at $4^{\circ} \mathrm{C}(7000 \mathrm{rpm}$ for $10 \mathrm{~min}$ ). The supernatant (15 liters) was concentrated by flash evaporator (below $28^{\circ} \mathrm{C}$ ), and the concentrate was dialyzed overnight against $0.001 \mathrm{M}$ acetate buffer ( $\mathrm{pH} 5.0$ ) and precipitated by ammonium sulfate fractionation $(0.2 \sim 0.8 \mathrm{sat}$.). The precipitate was dissolved thoroughly in $0.001 \mathrm{M}$ acetate buffer $(\mathrm{pH} \mathrm{5.0)}$ ) and dialyzed overnight against the same buffer using a strip of cellulose tubing. The dialyzate was then subjected to lyophilization (Daia style lyophilizer UFD-300FMS, Daiashinku Co., Ltd.) and used as the crude enzyme.

Assay of enzyme activity. The enzyme activities $\left(C_{1}\right.$ and $C_{x}$ enzyme activities) were assayed using filter paper (Toyo roshi No. 51 A, Toyo Kagaku Co., Ltd.) and CMC as substrates, as described in the previous paper. ${ }^{1 !}$

Preparation of cellulase from the cell wall fraction

a. Preparation of the cell wall fraction. For the preparation of the cell wall fraction, the organism was grown on CMC as the water-soluble carbon source for 2 to 3 days, since rice plant powder used thus far as the carbon source hindered the separation of the cells of $P$. oryzae. The medium was composed of $2.5 \mathrm{~g}$ of yeast extract, $20 \mathrm{ml}$ of stock solution, ${ }^{11} 20 \mathrm{~g}$ of CMC, and 1 liter of deionized water. It was autoclaved at $120^{\circ} \mathrm{C}$ for $20 \mathrm{~min}$. After subculture, culturing of $P$. oryzae was carried out as described in the previous paper, ${ }^{1}$ and the cells were harvested by filtration with a Buchner funnel, and washed sufficiently with deionized water. The packed cells were ground in a mortar with a suitable amount (1/5 of the wet cell wt.) of quartz sand and $0.01 \mathrm{~m}$ phosphate buffer $(\mathrm{pH} 7.0)$, and centrifuged at $800 \times g$ for $10 \min \left(2^{\circ} \mathrm{C}\right)$. The precipitate (with quartz sand) was washed sufficiently with $0.01 \mathrm{M}$ phosphate buffer $(\mathrm{pH} 7.0)$ until the enzyme activity could not be detected in the washed solution, and designated as the cell wall fraction.

b. Extraction of cellulase from the cell wall fraction. One-half gram of the cell wall fraction was suspended in $5 \mathrm{ml}$ of $0.01 \mathrm{M}$ phosphate buffer ( $\mathrm{pH} \mathrm{7.0)}$ containing one of the following extracting reagents, and cellulase was extracted from the cell wall fraction under shaking with a vibrator for $10 \mathrm{~min}$ at room temperature, and centrifuged at $800 \times g$ for $10 \mathrm{~min}\left(2^{\circ} \mathrm{C}\right)$. The enzyme activity in the supernatant was assayed according to the method described in the previous paper. ${ }^{11}$ The following various reagents were employed to extract cellulase from the cell wall fraction; 0.1 and $1 \% \mathrm{NaCl}, 0.1$ and $1 \% \mathrm{KCl}, 0.1$ and $1 \%$ sodium laurylsulfate, 0.1 and $1 \%$ Tween 80, $0.01 \mathrm{~m}$ EDTA, $3 \mathrm{M}$ urea and $\mathrm{BuOH}(\mathrm{BuOH}$ : $\mathrm{H}_{2} \mathrm{O}=3: 7$ ).

c. Method of freezing and thawing. One-half gram of the cell wall fraction was frozen below $-25^{\circ} \mathrm{C}$ (for $12 \mathrm{hr}$ ). The frozen cells, after added with $5 \mathrm{ml}$ of $0.01 \mathrm{M}$ phosphate buffer $(\mathrm{pH} 7.0)$, were thawed completely at $4^{\circ} \mathrm{C}$, and extracted with the buffer under shaking with a vibrator for $10 \mathrm{~min}$ at room temperature.

Column chromatography on DEAE-Sephadex A-50. DEAE-Sephadex A-50, activated by a conventional method and equilibrated with $0.01 \mathrm{~m}$ acetate buffer (pH 5.0) for $12 \mathrm{hr}$, was packed into a column (3.6x $25 \mathrm{~cm}$ ). Two hundred and fifty milligrams of the crude enzyme was dissolved in $5 \mathrm{ml}$ of the same buffer, and the precipitate was removed by centrifugation $(3000 \mathrm{rpm}$ for $10 \mathrm{~min}$ ). The supernatant was charged to the column, and the column was eluted successively with the same buffer containing various concentrations of $\mathrm{NaCl}(0,0.1,0.2,0.5$ and $0.7 \mathrm{M})$ at a velocity of $1 \mathrm{ml} /$ $\mathrm{min}$, and each $20 \mathrm{ml}$ was collected by fraction collector (in a cold room at $4^{\circ} \mathrm{C}$ ).

Column chromatography on Sephadex G-100. Sephadex $\mathbf{G}-100$, swollen by a conventional method, was suspended in $0.01 \mathrm{M}$ acetate buffer ( $\mathrm{pH} 5.0$ ) and packed into a column $(1.4 \times 100 \mathrm{~cm})$, and the column bed was 
stabilized by passing the same buffer for $24 \mathrm{hr}$. Then, $0.7 \mathrm{ml}$ of the enzyme solution was charged to the top of the column, and the column was eluted with the same buffer. Each $3 \mathrm{ml}$ fraction was collected at a velocity of $0.1 \mathrm{ml} / \mathrm{min}$.

\section{RESULTS}

Purification and comparison of the elution patterns on DEAE-Sephadex A-50 of cellulase from $P$. oryzae

In an attempt to elucidate the cause of difference in enzyme activities among various strains, the crude enzyme preparations of cellulase were subjected to DEAE-Sephadex A-50 chromatography. The elution patterns of the crude enzyme from various strains of $P$. oryzae are shown in Fig. 1 . Two fractions were obtained by this column; one passthrough fraction (Fraction I) and the other (Fraction II) adsorbed and eluted with $0.5 \mathrm{M}$ $\mathrm{NaCl}$. As can been seen in Fig. 1, the peak of fraction I was found to be comparatively high in the case of strongly pathogenic strains and low in the case of weakly pathogenic or
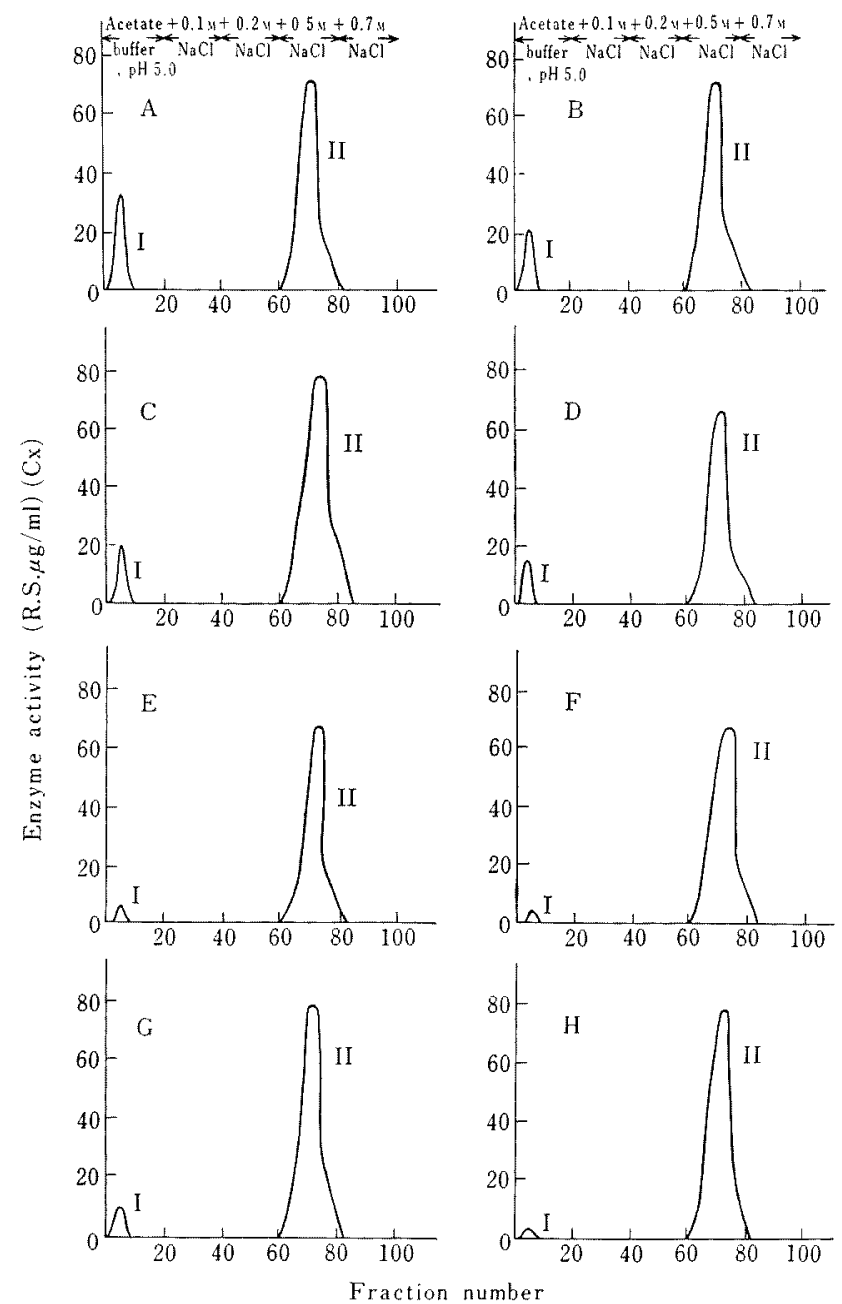

FIG. 1. Column Chromatography of Extracellular Cellulase on Sephadex A-50.

Each fraction $(20 \mathrm{ml})$ was collected and its $C_{x}$ enzyme activity was assayed.

A, strain T-1 (Ken 53-33); B, strain T-2 (Ken 62-89); C, strain (C-1 Ken 69-08); D, strain N-1 (H 373); E, strain C-3 (N 87); F, strain C-3 (F 67-2); G, strain O (THU 3×1); H, strain O (THU 65-01). 
nonpathogenic strains.

When the cellulase activity $\left(C_{x}\right.$ enzyme activity) in fraction $I$ expressed as percentage of the crude enzyme was compared among various strains, the differences in the activity characteristics of these strains were observed to be in parallel to the strength and scope in pathogenicity, except for the case of $\mathrm{C}-3$ strain of $P$. oryzae (Table I), confirming the

Table I. Cellulase Activity $\left(C_{x}\right.$ Enzyme Activity) Expressed as Percentage of Crude Enzyme in Fractions I and II

$\mathrm{C}_{\mathrm{x}}$ enzyme activity expressed as percentage of the crude enzyme (ammonium sulfate $0.2 \sim 0.8$ sat.) in fractions I and II was calculated. T-1, T-2, C-1, $\mathrm{N}-1$, pathogenic strains; $\mathrm{C}-3$, strain with pathogenic reversion phenomenon; $\mathrm{O}$, nonpathogenic strain (without appressorium and infecting hypha); $\mathrm{O}(\mathrm{S}$ 1-19), nonpathogenic strain (with appressorium and without infecting hypha).

\begin{tabular}{lcc}
\hline \multicolumn{1}{c}{ Strain } & Fraction I (\%) & Fraction II (\%) \\
\hline T-1 (Ken 53-33) & 20.8 & 79.0 \\
T-2 (Ken 62-89) & 8.0 & 92.0 \\
C-1 (Ken 69-08) & 4.7 & 95.3 \\
C-1 (TH 62-132) & 3.5 & 87.5 \\
C-3 (N 87) & 0.6 & 99.4 \\
C-3 (F 67-2) & 0.1 & 98.5 \\
N-1 (H 373) & 4.1 & 95.9 \\
O (THU 3 × 1) & 0.8 & 92.5 \\
O (THU 65-01) & 0.7 & 80.8 \\
O (S 1-19) & 0.4 & 96.0 \\
\hline
\end{tabular}

previous results. ${ }^{11}$ Furthermore, this difference in percentage was shown to be correlated to the difference in extracellular cellulase contents according to the strains, as demonstrated in the previous paper. ${ }^{11}$

When the ratio of $\mathrm{C}_{1}$ to $\mathrm{C}_{\mathrm{x}}$ enzyme activities in fractions $\mathrm{I}$ and II was compared among various strains, a higher value in the $C_{1} / C_{x}$ ratio was always observed in fraction $I$ than in fraction II, as shown in Table II.

Purification and comparison of elution patterns on Sephadex $G-100$ of extracellular cellulase from P. oryzae

Of fractions I and II separated by DEAESephadex A-50 chromatography, fraction I seemed to be responsible for the difference in
Table II. Comparison of the Ratio of $\mathrm{C}_{1}$ to $\mathrm{C}_{\bar{x}}$ Enzyme Activities In Fractions I AND II AMONG VARIOUS STRAINS

$\mathrm{C}_{1}, \mathrm{C}_{1}$ enzyme activity, expressed as R.S. $\mu \mathrm{g} / \mathrm{ml} / \mathrm{hr}$; $\mathrm{C}_{\mathrm{x}}, \mathrm{C}_{\mathrm{x}}$ enzyme activity, expressed as R.S. $\mu \mathrm{g} / \mathrm{ml} / \mathrm{hr}$; R.S., reducing sugar.

\begin{tabular}{lcc}
\hline \multirow{2}{*}{ Strain } & \multicolumn{2}{c}{$\mathrm{C}_{1} / \mathrm{C}_{\mathbf{x}}$} \\
\cline { 2 - 3 } & Fraction I & Fraction II \\
\hline T-1 (Ken 53-33) & 1.26 & 0.37 \\
T-2 (Ken 62-89) & 1.11 & 0.41 \\
C-1 (Ken 69-08) & 1.40 & 0.26 \\
C-3 (N 87) & 1.42 & 0.42 \\
C-3 (F 67-2) & 1.59 & 0.26 \\
N-1 (H 373) & 0.41 & 0.22 \\
O (THU 3 $\times 1)$ & 1.24 & 0.34 \\
\hline
\end{tabular}

Table III. Summary of Elution Patterns of Fractions I and II on Sephadex G-100 COLumn

Cellulase activities $\left(C_{x}\right)$ are expressed by symbols such as - (no activity), \pm (very low), + (low but clearly recognizable), ++ (relatively high), +++ (very high)

$\mathrm{T}-1, \mathrm{~T}-2, \mathrm{C}-1, \mathrm{~N}-1$, pathogenic strains; $\mathrm{C}-3$, strain with pathogenic reversion phenomenon; $O$, nonpathogenic strain (without appressorium and infecting hypha); O (S 1-19), nonpathogenic strain (with appressorium and without infecting hypha).

\begin{tabular}{|c|c|c|c|c|c|c|c|}
\hline \multirow{4}{*}{ Strain } & \multicolumn{7}{|c|}{ DEAE-Sephadex A-50 } \\
\hline & \multicolumn{2}{|c|}{ I } & \multicolumn{5}{|c|}{ II } \\
\hline & \multicolumn{7}{|c|}{ Sephadex G-100 } \\
\hline & a & b & $\mathrm{c}$ & $\mathrm{d}$ & $\mathrm{e}$ & $\mathrm{f}$ & $\mathrm{g}$ \\
\hline $\mathrm{T}-1($ Ken $53-33)$ & 井 & + & + & $H$ & 井 & + & $H$ \\
\hline T-2 (Ken 62-89) & + & H & + & $H$ & $H$ & + & $H$ \\
\hline $\mathrm{T}-2(\mathrm{H} 63-20)$ & + & $H$ & + & $H$ & H & \pm & $H$ \\
\hline C-1 (Ken 69-08) & + & H & + & \pm & Ht & \pm & H \\
\hline C-1 (TH 62-132) & + & H & + & \pm & $H$ & \pm & $H$ \\
\hline $\mathrm{C}-3(\mathrm{~N} 87)$ & $H$ & - & + & + & $H$ & + & - \\
\hline $\mathrm{C}-3(\mathrm{~F} 67-2)$ & - & - & + & + & H & + & - \\
\hline $\mathrm{N}-1$ (H 373) & - & H & + & + & th & + & H \\
\hline N-1 (Ken 69-07) & - & $H$ & + & + & 州 & + & H \\
\hline $\mathrm{O}(\mathrm{THU} 3 \times 1)$ & + & - & + & + & H & - & - \\
\hline O (THU 65-01) & - & - & + & + & 世 & - & - \\
\hline $\mathrm{O}(\mathrm{S} 1-19)$ & - & - & + & H & W & - & \pm \\
\hline
\end{tabular}

enzyme contents among various strains. Then, cellulases in fractions I as well as II were further purified by gel filtration, in order to investigate the fraction responsible for the difference in enzyme activities.

On fractionation of the fractions I and II 


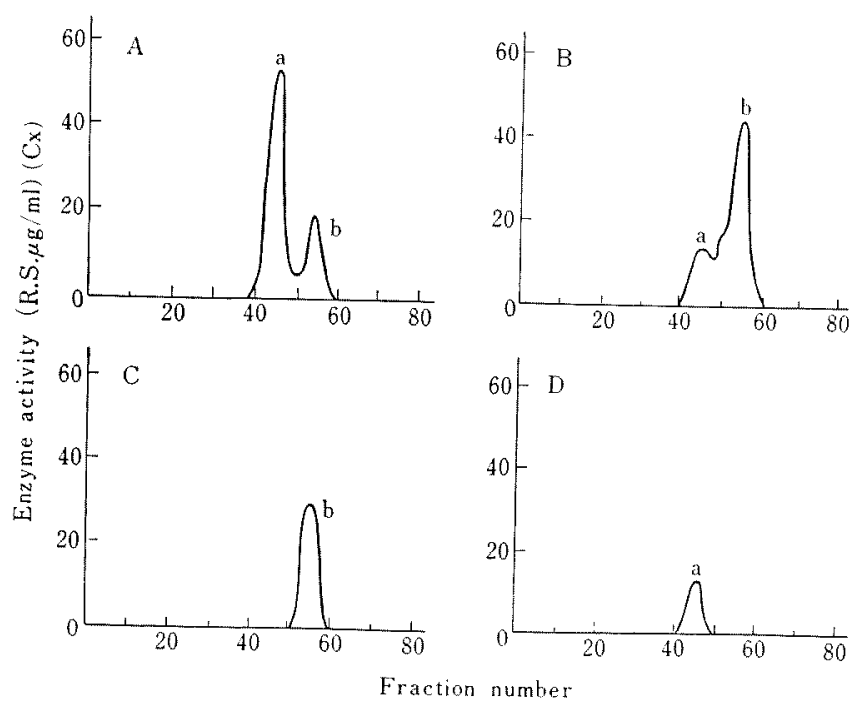

FIG. 2. Chromatography of Fraction I on Sephadex G-100 Column.

Fraction I (Fig. 1) was concentrated by ultrafiltration and lyophilized, and subjected to Sephadex G-100 chromatography. Three milliliters was collected in each fraction and enzyme activity was expressed as $C_{x}$ enzyme activity.

A, strain T-1 (Ken 53-33); B, strain C-1 (Ken 69-08); C, strain N-1 (H 373); D, strain O (THU $3 \times 1$ ).

on Sephadex G-100 column, the former was separated into two components (peaks a and $b$ ) and the latter was fractionated into at least five (peaks c, d, e, f and $g$ ). The results are shown in Figs. 2 and 3.

Next, the height of these seven peaks was compared among various strains. As summarized in Table III, a large peak a and remarkably small peak $b$ were observed with $\mathrm{T}-1$ (Ken 53-33) strain, but the situation was reversed in the case of $\mathrm{T}-2$ and $\mathrm{C}-1$ strains of $P$. oryzae. Only peak a was detected in the case of $\mathrm{C}-3(\mathrm{~N} 87)$ strain and non-pathogenic $\mathrm{O}$ (THU $3 \times 1$ ).

On the other hand, in the case of fraction II, peaks $c$ and $e$ were detected in common among all the strains. Peak $g$ and peaks $f$ and $g$ could not be recognized in the case of $\mathrm{C}-3$ strain and $\mathrm{O}(\mathrm{THU} 3 \times 1)$ and $\mathrm{O}$ (THU 65-01) strains, respectively.

Possible reason for the low activity of extracellular cellulase from $C-3$ strain

$\mathrm{C}-3$ strain of $P$. oryzae, showing the pathogenic reversion phenomenon, has been shown to be remarkably low in extracellular cellulase activity, ${ }^{1)}$ and thus forms an exception to the correlation thus far demonstrated between difference in enzyme activities and pathogenicity among various strains. Since this low extracellular enzyme activity might possibly be due to the defect in the excretion mechanism of the cellulase into the medium, the cellulase activity in the cell wall fraction of $P$. oryzae was examined and compared among various strains.

The extraction method of cellulase from the cell wall fraction, prepared by grinding cells with quartz sand, was examined first. As shown in Table IV, it was confirmed that the cellulase was extracted most effectively when the cell wall fraction was shaken with $1 \%$ $\mathrm{KCl}$ or $\mathrm{NaCl}$. Activities of the cellulase thus extracted with $1 \% \mathrm{NaCl}$ from the cell wall fraction were then compared among various strains. The result is shown in Table $\mathrm{V}$. The $\mathrm{C}-3$ strain of $P$. oryzae exhibited higher cellulase activities $\left(C_{1}\right.$ and $C_{x}$ enzyme activities) than other strains tested so far. This tendency was consistently observed, even 

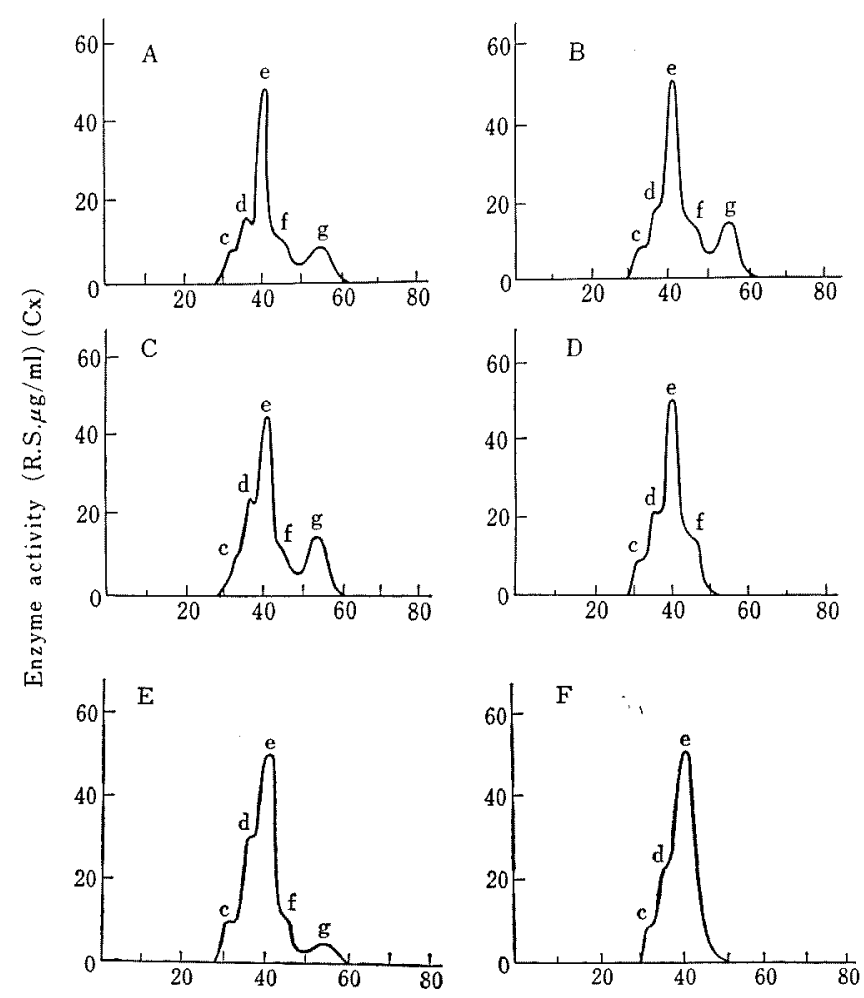

Fraction number

FIG. 3. Chromatography of Fraction II on Sephadex G-100 Column.

Fraction II (Fig. 1) was concentrated by ultrafiltration and lyophilized, and subjected to Sephadex G-100 chromatography. Three milliliters was collected in each fraction and enzyme activity was expressed as $\mathrm{C}_{\mathrm{x}}$ enzyme activity.

A, strain T-1 (Ken 53-33); B, strain T-2 (Ken 62-89); C, strain C-1 (Ken 69-08); D, strain C-3 (N 87); E, strain N-1 (H 373); F, strain O (THU $3 \times 1$ ).

though the 2 or 3 day-old culture was examined. Thus the C-3 strain proved to possess a remarkably high cellulase activity, so far as the enzyme in the cell wall fraction is concerned, as compared with other strains tested.

\section{DISCUSSION}

By carrying out the partial purification of extracellular cellulase from $P$. oryzae, the relationship between the degree of pathogenicity and the enzyme activities as observed in the previous paper ${ }^{1 /}$ was found to apply to the elution patterns on column chromatography.

The possible relationship between the degree of pathogenicity and the height of each peak may thus be suggested, comparing the reported pathogenecity with the height of peaks a and $b$ of various strains (Table III). This might be taken to show that the difference in the enzyme activity was due to peaks $a$ and $b$. However, the low extracellular enzyme activities of $\mathrm{C}-3$ ( $\mathrm{N} 87$ ) and $\mathrm{O}$ (THU $3 \times 1$ ) strains $^{13}$ might not be explained solely by the relationship described above, since peak a was also observed in $\mathrm{C}-3$ (N 87) and $\mathrm{O}$ (THU $3 \times 1)$ strains, which had been shown to be low in enzyme activity and in which the percentage of enzyme activity in fraction I (to crude enzyme) was far less than the others.

The phenomenon of synergism has been known to occur in the cellulases from Trichoderma sp. and Aspergillus $\mathrm{sp}^{2 \sim 51}$ If the 
Table IV. Extraction of Cellulase Activity from Cell Wall Fraction by Various TREATMENTS

The cell wall fraction, prepared from strain $\mathrm{N}-1$ (H 373) of $P$. oryzae, was extracted by the following treatments (under shaking with a vibrator for $10 \mathrm{~min}$ at room temperature), Cellulase activity was expressed as $\mathrm{C}_{\mathbf{z}}$ enzyme activity. R.S.: Reducing sugar.

\begin{tabular}{lc}
\hline Treatments & $\begin{array}{c}\text { Enzyme activity } \\
\left(\mathrm{C}_{\mathrm{x}}\right)\end{array}$ \\
R.S. $\mu \mathrm{g} / 6.4 \mathrm{ml} / 10 \mathrm{~min}$
\end{tabular}

Table V. Comparison of Cellulase activities

( $C_{1}$ AND $C_{x}$ Enzyme Activities) of The Cell

Wall Fraction among Various Strains

From cell wall fractions, prepared from various strains, the cellulase was extracted with $1 \% \mathrm{NaCl}$ using a vibrator (for $10 \mathrm{~min}$ at room temperature), and the enzyme activity was determined.

$\mathrm{T}-1, \mathrm{~N}-1$, pathogenic strains; $\mathrm{C}-3$, strain with pathogenic reversion phenomenon; $\mathrm{O}$, nonpathogenic strain (without appressorium and infecting hypha). R.S.: Reducing sugar.

\begin{tabular}{|c|c|c|c|}
\hline Strain & $\begin{array}{l}\text { Culture } \\
\text { time } \\
\text { (days) }\end{array}$ & $\begin{array}{c}\text { Cellulas } \\
\text { CI enzyme } \\
\text { (R.S. } \mu \mathrm{g} / \mathrm{ml} / \\
50 \mathrm{hr} \text { ) }\end{array}$ & $\begin{array}{c}\text { e activity } \\
\mathrm{C}_{\pi} \text { enzyme } \\
\text { (R.S. } \mu \mathrm{g} / \mathrm{ml} / \\
\text { min) }\end{array}$ \\
\hline \multirow[t]{2}{*}{$\mathrm{T}-1(\mathrm{Ken} 53-33)$} & 2 & 153.8 & 4.5 \\
\hline & 3 & 156.8 & 5.0 \\
\hline \multirow[t]{2}{*}{$\mathrm{C}-3(\mathrm{~N} 87)$} & 2 & 657.7 & 6.2 \\
\hline & 3 & 671.8 & 18.6 \\
\hline \multirow[t]{2}{*}{ N-1 (H 373) } & 2 & 94.8 & 3.9 \\
\hline & 3 & 64.2 & 3.6 \\
\hline \multirow[t]{2}{*}{$\mathrm{O}($ THU $3 \times 1)$} & 2 & 94.9 & - \\
\hline & 3 & 152.8 & 5.0 \\
\hline
\end{tabular}

same phenomenon exists in the cellulase from $P$. oryzae, it might be supposed to have signifi- cance that peak $f$ and peaks $f$ and $g$ could not be detected in the case of $\mathrm{C}-3$ strain and $\mathrm{O}$ strain, respectively. Therefore, enzymatic properties must be examined with each component purified to a homogeneous state.

Extracellular cellulase of $P$. oryzae was separated into two components, basic and acidic proteins, of which the latter constituted the greater part. ${ }^{6}$ The basicity of former seemed to be weak, since it passed through CM-Sephadex and had a low mobility in starch zone electrophoresis. The cellulases from Trichoderma sp. and Aspergillus sp. have been reported to be of high and low specific activities, respectively.

Fractions I and II seem to represent $C_{1}$ and $C_{x}$ enzyme activity-rich fractions, respectively, based on the ratio of $C_{1}$ to $C_{x}$ enzyme activities in each fraction separated by DEAE-Sephadex A-50. Although this fact may be taken to suggest the existence of different entities for $C_{1}$ and $C_{x}$ enzyme activities, we think at present that a single enzyme protein is responsible for the both activities, because of the following evidence; 1) $C_{1}$ rich component, purified to exhibit a homogeneity in electrophoresis, was always accompanied by a trace of $\mathrm{C}_{x}$ enzyme activity. ${ }^{7,8)}$ 2) $C_{1}$ enzyme activity, generally undetectable in the filtrate cultured with $\mathrm{CMC}$ as carbon source, was rendered demonstrable by alcohol precipitation or DEAE-Sephadex A-50 treatment of the filtrate. ${ }^{9}$ These findings, therefore, suggest that $C_{1}$ and $C_{x}$ enzyme actions may be due to the identical protein, and that the relative ratio of $C_{1}$ and $C_{x}$ enzyme activities in fractions I and II may be regulated by the occurrence, and the relative amount, of some regulatory factors in each fraction.

Since the cellulase in the cell wall fraction of $P$. oryzae was shown to be easily extracted with $1 \% \mathrm{NaCl}$ or $\mathrm{KCl}$, it was suggested that the enzyme was bound to the cell wall by ionic bonds. Yabuki et al. ${ }^{10 \sim 12)}$ have proposed a model of the excretion mechanism of $\alpha$ amylase in Aspergillus oryzae, as shown in Fig. 4. If the excretion of cellulase in $P$. oryzae should be assumed to follow essential- 


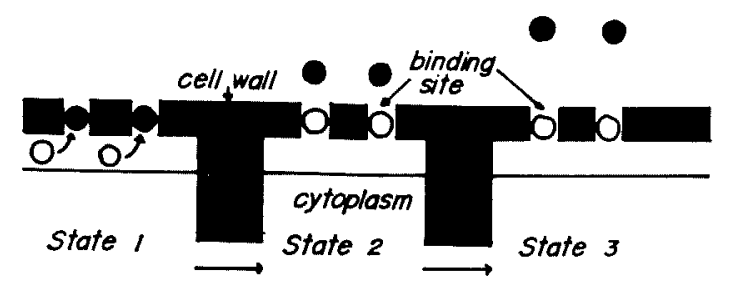

Fig. 4. A Model of Excretion of a-Amylase from Aspergillus oryzae (Yabuki and Fukui). ${ }^{10 \sim 12)}$

-, $a$-amylase; $\bigcirc$, masking factor.

ly the same mechanism as proposed by Yabuki et al., one of the reason for the high intracellular cellulase activity in the case of $\mathrm{C}-3$ strain as shown in the present experiments, would be the defect or abnormality in either the binding site or masking factor in the cell wall fraction of this particular strain of P. oryzae.

\section{REFERENCES}

1) T. Sudo, H. Nagayama and K. Tamari, Agr.
Biol. Chem., 37, 1651 (1973).

2) M. Mandels and E. T. Reese, Develop. Ind. Microbiol., 5, 5 (1964).

3) K. Selby and C. C. Maitland, Biochem. J., 104, 716 (1967).

4) T. M. Wood, ibid., 109, 217 (1968).

5) idem, ibid., 115, 457 (1969).

6) T. Sudo and K. Tamari, unpublished data.

7) T. M. Wood and S. I. Mccrae, Biochem. J., 128, 1183 (1972).

8) K. Nishizawa, Y. Tomita, T. Kanda, H. Suzuki, and K. Wakabayashi, Abst. 4th Int. Fermentation Symp., Kyoto, p. 141 (1972).

9) T. Hirayama, T. Sudo and K. Tamari, unpublished data.

10) M. Yabuki and S. Fukui, Seikagaku, 41, 549 (1969).

11) M. Yabuki and S. Fukui, J. Bacteriol., 104, 138 (1970).

12) M. Yabuki, K. Hoshino and S. Fukui, Seikagaku, 42, 666 (1970). 